\title{
CFG pile + vibro-replacement stone column pile to treat soil liquefaction on power plant
}

\author{
Ming Zhang ${ }^{1 \mathrm{a}}$; Baoming Wang ${ }^{1 \mathrm{~b}}$; Songjiang Wang ${ }^{1 \mathrm{c}}$ \\ ${ }^{1}$ Henan Electric Power Survey and Design Institute, Henan, China \\ azhangming-heny@powerchina.cn, b'wangbaoming-heny@powerchina.cn, \\ wangsongjiang-heny@powerchina.cn
}

\begin{abstract}
Keywords: silt, liquefaction, foundation treatment, CFG pile, vibro-replacement stone column pile. Abstract. Silt foundation of the power plant in Shangqiu area was select as the research object, to verification the effect of foundation treatment for CFG pile and CFG pile + vibro-replacement stone column pile methods. The results showed that: bearing capacity of the foundation was improved after the CFG pile or CFG + vibro-replacement stone column composite foundation, the characteristic value of subsoil bearing capacity increase from $111 \mathrm{kPa}$ to $256 \mathrm{kPa}$ or $332 \mathrm{kPa}$, respectively. The value of bearing capacity increment after treatment by the two methods is in the same order of magnitude. However, the liquefaction of silt foundation can be eliminated by treatment with CFG pile + vibro-replacement stone column pile. It is concluded that the value of bearing capacity after treatment by the two methods is both meet the requirement of the auxiliary building in power plant, and which one is suitable is based on whether the building is sensitive to liquefaction.
\end{abstract}

\section{Introduction}

Liquefaction occurs in saturated silt ground in the case of seismic, leading to the loss of carrying capacity, a greater differential settlement, moreover, causing buildings to crack, tilt and destruction. Common ground liquefaction eliminates method are compaction method (vibroflotation method, vibrating chip pile, vibrating pressing sandstone pile and Dynamic compaction method, etc.) and replacement method ${ }^{[1][2]}$. When the engineering properties of liquefaction ground are poor, the mentioned methods above are not enough. based on the principle that bearing capacity of foundation treatment by CFG pile can be increased, and liquefaction can be eliminated by treatment with vibro-replacement stone column pile, the paper proposes the use of foundation treatment methods by CFG pile + vibro-replacement stone column pile. The static loading tests were done to verify the effect of foundation treatment, providing reliable test data for the study of liquefaction soil foundation with low carrying capacity.

\section{Test site}

Test site belongs to the Huai River alluvial plain, the topography is flat and the terrain is open. Geotechnical engineering investigation results indicate that the foundation soil is mainly composed of silt, silty clay. The foundation soil belongs to Liquefied soil. The exposed strata in geotechnical exploration depth are divided into twelve layers, as shown in Figure 1. 


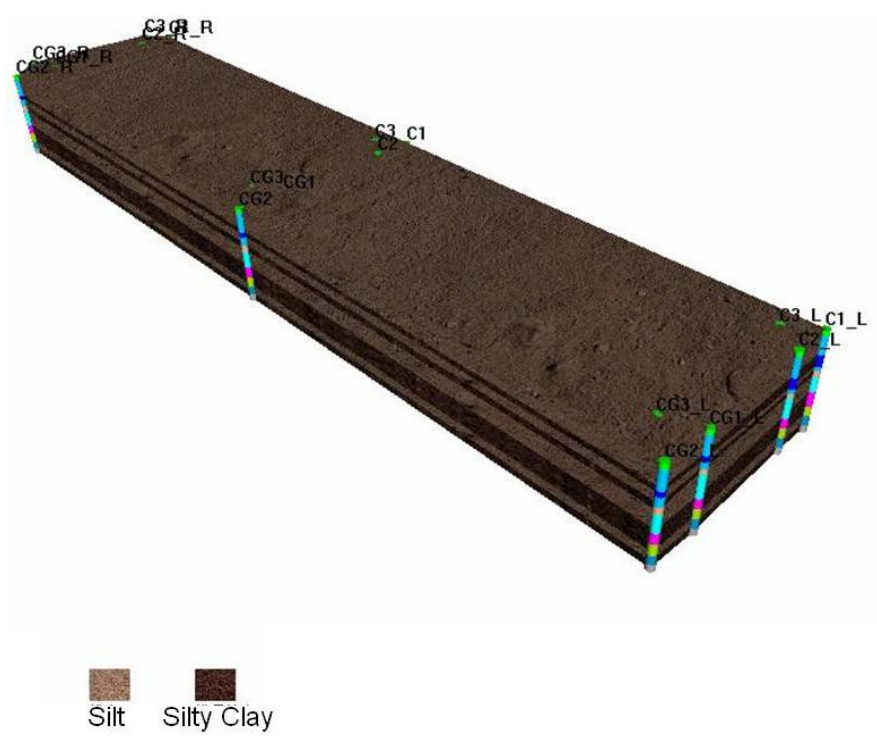

Fig. 1 exposed strata in the test site

\section{Test design}

The plane size of the second one is $6.40 \mathrm{~m} \times 8.00 \mathrm{~m}$, pile spacing is $1.60 \mathrm{~m}$. there are six rows of $30 \mathrm{CFG}$ piles, arranged in square. The length is $15.0 \mathrm{~m}$. The second plane include $42 \mathrm{CFG}$ piles and 18 vibro-replacement stone column pile, which were interlaced and normal arrangement, pile spacing is $0.80 \mathrm{~m}$. The lengths of CFG pile and vibro-replacement stone column pile is $15 \mathrm{~m}$ and $10.0 \mathrm{~m}$. CFG Pile top located under the natural ground about $3.80 \mathrm{~m}$ (layer(2) silt) and pile tip located under the layer6) silt.

\section{Bearing capacity}

Three groups of static loading test for ground before and after measured, following code for design of building foundation in China ${ }^{[3][4]}$. All “ $\mathrm{p}$ - s" curves are shown in Fig.2, Fig.3 and Fig.4, including soil without treatment, foundation treatment for CFG pile and CFG pile + vibro-replacement stone column pile methods. The characteristic values of subsoil bearing capacity of soil before treatment, treatment for CFG pile, and treatment for CFG pile + vibro-replacement stone column pile in the test is $111 \mathrm{kPa}, 257 \mathrm{kPa}$, and $332 \mathrm{kPa}$.

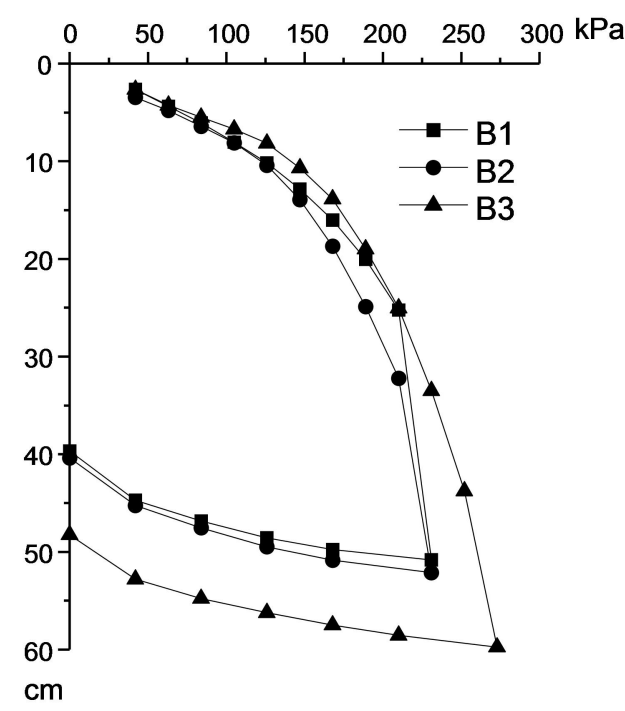

Fig.2 p-s curve of foundation before treatment 


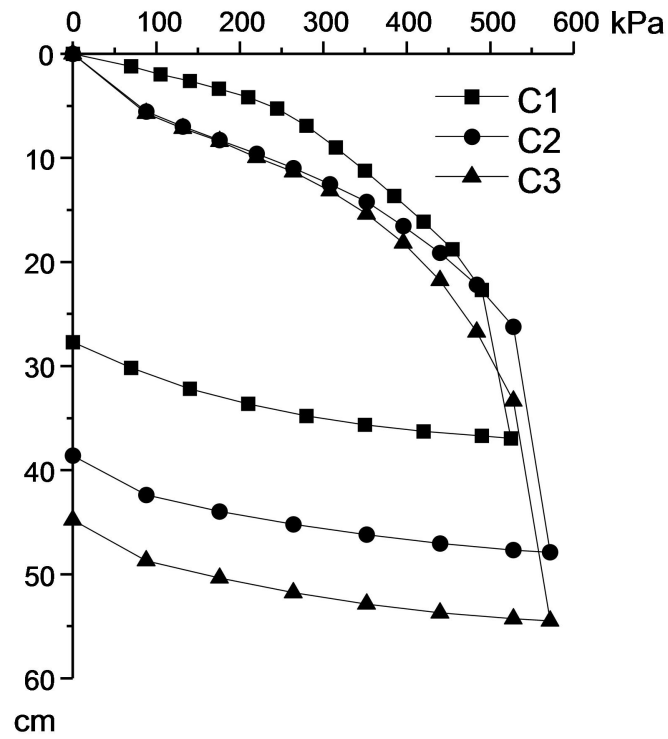

Fig.3 p-s curve of foundation after treatment with CFG pile

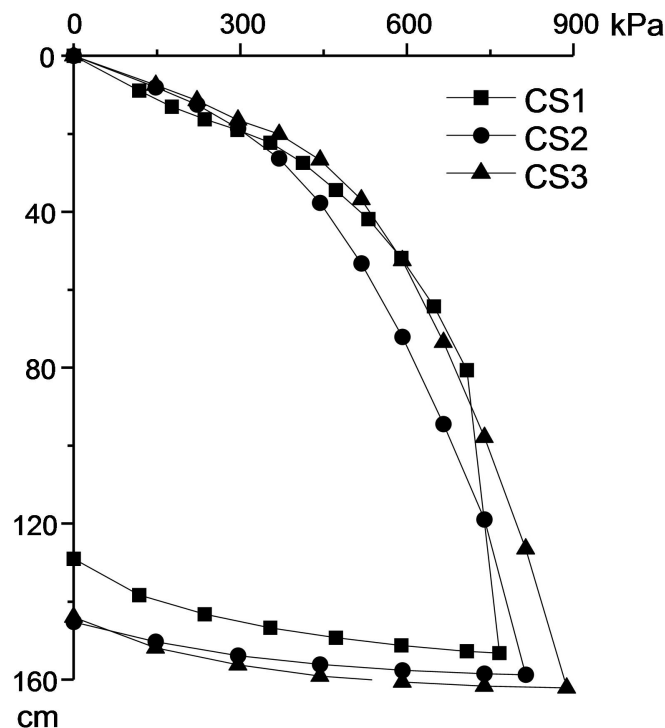

Fig.4 p-s curve of foundation after treatment with CFG pile+vibro-replacement stone column pile It can be seen from the figures that the CFG pile or vibro-replacement stone column pile can improve the bearing capacity of the foundation, the bearing capacity increased from $111 \mathrm{kPa}$ to $257 \mathrm{kPa}$, the improvement rate is obvious, more than 1 times. Compared with CFG pile composite foundation, the CFG + vibro-replacement stone pile composite foundation increased from 257 to 332 $\mathrm{kPa}$, and the increase rate was not obvious. It is shown that the effect of CFG pile on the bearing capacity of foundation soil is obvious, and the effect of vibro-replacement stone pile on the bearing capacity is limited, which also reflects that its main role is not to improve the bearing capacity of foundation soil.

\section{Liquefaction analysis}

The standard penetration test and grain size test were used to analysis the soil liquefaction of composite foundation, based on the same criterion condition to the soil before treatment. The Standard Penetration Number increases obviously to soil between piles in the test area. Before 
treatment, liquefaction grade for layer (1), (2), (2) 1 and layer (4) is medium. After treatment with CFG+vibro-replacement stone column pile, the liquefaction grade decreased to slightly, the liquefaction potential of the soil in the test area is basically eliminated, except that the liquefaction potential of the silt is about $3.50 \mathrm{~m}$. The soil can be crowded by vibro-replacement stone column pile to achieve the purpose of eliminating the liquefaction potential of the foundation soil.

In general, $257 \mathrm{kPa}$ and $332 \mathrm{kPa}$ can meet the load requirements of power plant ancillary buildings, such as cooling towers. Therefore, CFG + vibro-replacement stone column pile can be used for the liquefaction-sensitive power plant ancillary buildings.

\section{Conclusions}

Engineering properties of composite foundation with CFG pile + vibro-replacement stone column pile in liquefaction area were measured by field static loading test, and the treatment effect was analysis. It is conclusion that:

The CFG pile and CFG pile + vibro-replacement stone column pile treatment can greatly improve the bearing capacity of foundation soil, the effect almost the same, more than one time.

It is found that the liquefaction grade of the CFG pile +vibro-replacement stone column pile is reduced from medium to slight and below, and the liquefaction potential is basically eliminated.

When designing the power plant, CFG + vibro-replacement stone column pile can be used for the liquefaction-sensitive power plant ancillary buildings. To the buildings liquefaction is not sensitive, CFG pile can be used.

\section{References}

[1] Chang Shi Biao, etc. Engineering Geology Manual (fourth edition) [M]. Beijing: China building Industry Press, 2012.

[2] Singh, S. Liquefaction characteristics of silts[J]. Geotechnical and Geological engineering, 1996, 14: $1-19$.

[3] MOHURD. Code for design of building foundation[S]. Beijing: China architecture and building press, 2012.

[4] MOHURD. Technical code for testing of building foundation piles[S]. Beijing: China architecture and building press, 2012. 